\title{
Patients and Healthcare Providers' Attitudes and Perceptions of Drug-related Problems in Saudi Arabia
}

\author{
Yousef Ahmed Alomi ${ }^{1}{ }^{*}$, Awatif Saad Al-Shaibani ${ }^{2}$, Ghadeer Alfaisal' ${ }^{2}$, Njood Mohmmed Alasmi ${ }^{2}$ \\ ${ }^{1}$ The Past General Manager of General Administration of Pharmaceutical Care and Head, National Clinical pharmacy, pharmacy \\ practice and Pharmacy $R$ and D Administration, Ministry of Health, Riyadh, KSA. \\ ${ }^{2}$ Clinical Pharmacy Staff, Ministry of Health, P.O.BOX 100, Riyadh 11392, Riyadh, KSA.
}

Received: 23 February 2018; Accepted: 11 May 2018

*Correspondence to:

Dr. Yousef Ahmed Alomi, The Past General Manager of General Administration of Pharmaceutical Care Past Head, National Clinical pharmacy, and pharmacy practice, Past Head, Pharmacy R and $D$ Administration Ministry of Health, P.O.BOX 100, Riyadh 11392, Riyadh, SAUDI ARABIA. Email:yalomi@gmail.com

Copyright: (ㅇ the author(s),publisher and licensee Indian Academy of Pharmacists. This is an open-access article distributed under the terms of the Creative Commons Attribution Non-Commercial License, which permits unrestricted non-commercial use, distribution, and reproduction in any medium, provided the original work is properly cited.

\begin{abstract}
Purpose: To explore the patients and healthcare providers' attitudes and perceptions of drug-related problems in Saudi Arabia. Methods: It is a 4-months cross-sectional survey of drug-related problem information in Saudi Arabia. The study consisted of two-part a demographic data, and second part contained the questions about the knowledge of drug-related problems, the frequent occurrence, the type of medication-induced those problems, and the resources information used about the drug-related problem. American Society of HealthSystem Pharmacist definitions of drug-related problems used. The 5-point Likert response scale system used. The survey distributed through social media. The questionnaire made of an electronic format, and it analyzed through survey monkey system. Results: The total responders were two hundred and one; the Saudi nationality was 188 (93.5\%), and non-Saudi was 13 (6.5\%) patient. The gender distribution was female $180(89.6 \%)$, and the male was $21(10.4 \%)$. The majority of them in age (18-44) $88 \%$ and located in Riyadh region $84(41.8 \%)$ and Asir region 59 (29.4\%). Of those $44(22.1 \%)$ were healthcare providers. The majority of responders showed good knowledge about medication non-compliance 150 (75.76\%), and medication without indication 147 (73.1\%), while an adequate revealed information of adverse drug reaction $128(64 \%)$, and an indication without medication 124 (62\%). The imperfect information found about drug interaction 75 $(37.5 \%)$ and drug poisoning $89(44.5 \%)$. The most frequent drug-related problems occurred with the patient last year at least once; it was drug noncompliance 142 (71.4\%), indications without medication 100 (50\%), and adverse medication events 80 (40\%). The most resources information on drug-related problems used were the internet, medicine leaflet, and healthcare practitioners. Conclusion: Drug-related problems occurred at a high rate in Saudi patients. The knowledge of drug-related problems is not adequate. It is very demanding and comprehensive public education about medication and urgent implementation of the patient medications counseling program in Saudi Arabia.
\end{abstract}

Key words: Patients, Healthcare providers, Attitudes, Perceptions, Drug-related problems, Saudi Arabia.

\section{INTRODUCTION}

The treatment of disease needs several steps starting from the assessment of the patient with subjective and objective analysis. Followed by the interpretations of all subjects and objective investigations and results. Also, the plan of treatment with lifestyle and drug therapy. During medications therapy and providing the optimal the pharmaceutical care to the patients, several problems may occur for instance; but not limited to the medications errors, adverse drug reaction, and failure to receive medications, indication without medications and medication without indications. ${ }^{[1-3]}$ Those problems may occur accidentally. Alternatively, sometimes if the patients increase the dosing drug therapy or wrong administration or stop some medications by himself that is maybe the impact of patient perspective. The drug-related problems occur at a high rate $85 \%$ of patients had at least one DRP and $29 \%$ had five or more DRPs. ${ }^{[4]}$ Thirty-four percent of hospital elderly patient experiences with one or more adverse drug reaction. ${ }^{[5]}$ Fifty percent of hospitalizations due to drug-related problems deemed preventable..$^{[4]}$ Several studies conducted to explore the drug-related problems patient attitudes and perspectives. Most of the studies asked particular medications and disease and included the drug-related problems among patients general medications knowledge. It seldom to find a study to explore drug-related problems healthcare professionals and patient attitudes perspectives in Saudi Arabia or Gulf and Middle East counties or even worldwide. ${ }^{[6]}$ The objective of the study to explore the drug-related problems healthcare professionals and patient attitudes in Kingdom of Saudi Arabia.

\section{METHOD}

It is a 4-months cross-sectional survey of drug-related problem information in Saudi Arabia. The survey consisted of two-part demographic information, and second part consisted of 13 questions focusing on general knowledge of drug-related problems, their occurrence, and costs. The questions divided into three domains. It included domain 1: Primary or essential information about knowledge and perception of drug-related problems, domain 2: The cost analysis of drug-related problems, domain 3: Clinical outcome of drug-related problems. The questions about the knowledge of drug-related problems, the frequent occurrence, and the type of medication-induced those problems. Also, the resources information used in the drug-related problem. American Society of Health-System Pharmacist definitions of drug-related problems used. ${ }^{[1-3,7]}$ The 5 -point Likert response scale system used. The questions were open and closed-ended. The survey distributed through social media around Saudi Arabia. The survey distributed through social media by using 


\section{Alomi, et al.: Attitudes about drug related problems among HCPs and Patients}

what's App to almost two thousand public and healthcare professionals overall Kingdom of Saudi Arabia. A messages reminders sent to healthcare professional after two weeks, and additional messages reminders sent to healthcare professional after four weeks. The survey made an electronic format, and it analyzed domain three Primary or essential information about knowledge and perception of drug-related problems through survey monkey system.

\section{RESULTS}

The total responders were one hundred and one. Of those $155(77.9 \%)$ were patients while $44(22.1 \%)$ were healthcare professionals. Of those, the Saudi nationality was 188 (93.5\%), and Saudi was 13 (6.5\%). It is statistically significant in Saudi and non-Saudi between there patient and healthcare professionals. The patients were high in the Saudi nationality while with healthcare professionals higher in the non-Saudi nationality. The gender distribution was female $180(89.6 \%)$, and the male was $21(10.4 \%)$. It is statistically non-significant $(p<0.5)$ in the in the female and males between Patient and healthcare professionals. The most age was (18-44) represented the eighty-eight percent of responders. There is no statistically significant between all age categories between patient and healthcare professionals expert in the age (18-29) years. The total most healthcare professionals were pharmacist $34(65.38 \%)$, and nurses were six $(11.54 \%)$ followed by others $5(9.62 \%)$, dentist $4(7.69 \%)$ and $3(5.77 \%)$ physicians. The most responders' qualifications had the Bachelor Degree 137(68.2\%). Followed by High school $30(14.9 \%)$ and Master degree $18(9 \%)$. There is no statistically significant difference in the academic qualifications between patient and healthcare professionals $(\mathrm{p}<0.5)$ as explored in Table 1.The majority of responders showed good knowledge about medication non-compliance 150

\begin{tabular}{|c|c|c|c|c|c|c|}
\hline Characteristics & $\begin{array}{l}\text { Patients } \\
\text { n (\%) }\end{array}$ & $\begin{array}{l}\text { Healthcare } \\
\text { Professionals } \\
\text { n (\%) }\end{array}$ & $\begin{array}{l}\text { Total } \\
\text { comparisons } \\
\mathrm{n}(\%)\end{array}$ & Total N & Total \% & P value* \\
\hline \multicolumn{7}{|l|}{ Sex } \\
\hline Female & $138(89.03 \%)$ & $40(90.91 \%)$ & $178(89.45 \%)$ & 180 & $89.6 \%$ & $>0.05$ \\
\hline Male & $17(10.97 \%)$ & $4(9.09 \%)$ & $21(10.55 \%)$ & 21 & $10.4 \%$ & $>0.05$ \\
\hline Answered question & $155(77.89 \%)$ & $44(22.11 \%)$ & 199 & 201 & & \\
\hline Skipped question & & & 2 & 0 & & \\
\hline \multicolumn{7}{|l|}{ Nationality } \\
\hline Saudi & $151(97.42 \%)$ & $35(79.55 \%)$ & $186(93.47 \%)$ & 188 & $93.5 \%$ & $<0.05$ \\
\hline Non-Saudi & $4(2.58 \%)$ & $9(20.45 \%)$ & $13(6.53 \%)$ & 13 & $6.5 \%$ & $<0.05$ \\
\hline Answered question & $155(77.89 \%)$ & $44(22.11 \%)$ & 199 & 201 & & \\
\hline Skipped question & & & 2 & 0 & & \\
\hline \multicolumn{7}{|l|}{ Age } \\
\hline$<18$ & $1(0.65 \%)$ & $0(0.00 \%)$ & $1(0.50 \%)$ & 1 & $0.5 \%$ & $>0.05$ \\
\hline $18-29$ & $80(51.61 \%)$ & $33(75.00 \%)$ & $113(56.78 \%)$ & 113 & $56.2 \%$ & $<0.05$ \\
\hline $30-44$ & $53(34.19 \%)$ & $9(20.45 \%)$ & $62(31.16 \%)$ & 64 & $31.8 \%$ & $>0.05$ \\
\hline $45-59$ & $21(13.55 \%)$ & $2(4.55 \%)$ & $23(11.56 \%)$ & 23 & $11.4 \%$ & $>0.05$ \\
\hline $60+$ & $0(00.00 \%)$ & $0(00.00 \%)$ & $0(00.00 \%)$ & 0 & $0.0 \%$ & $>0.05$ \\
\hline Answered question & $155(77.89 \%)$ & $44(22.11 \%)$ & 199 & 201 & & \\
\hline Skipped question & & & 2 & 0 & & \\
\hline \multicolumn{7}{|l|}{ Healthcare providers } \\
\hline Yes & $0(00.00 \%)$ & $44(100.0 \%)$ & $44(22.11 \%)$ & 44 & $22.1 \%$ & $<0.05$ \\
\hline Non & $155(100.0 \%)$ & $0(00.00 \%)$ & $155(77.89 \%)$ & 155 & $77.9 \%$ & $<0.05$ \\
\hline Answered question & $155(77.89 \%)$ & $44(22.11 \%)$ & 199 & 199 & & \\
\hline Skipped question & & & 2 & 2 & & \\
\hline Type of healthcare professional & & & & Response Count & Response Percent & \\
\hline Physician & & & & 3 & $5.77 \%$ & \\
\hline Dentist & & & & 4 & $7.69 \%$ & \\
\hline Pharmacist & & & & 34 & $65.38 \%$ & \\
\hline Nurse & & & & 6 & $11.54 \%$ & \\
\hline Others & & & & 5 & $9.62 \%$ & \\
\hline Answered question & & & & 52 & & \\
\hline Skipped question & & & & 0 & & \\
\hline Academic Qualifications & & & & Response Count & Response Percent & \\
\hline Doctorate degree & $4(2.58 \%)$ & $3(6.82 \%)$ & $7(3.52 \%)$ & 7 & $3.5 \%$ & $>0.05$ \\
\hline Master degree & $15(9.68 \%)$ & $2(4.55 \%)$ & $17(8.54 \%)$ & 18 & $9.0 \%$ & $>0.05$ \\
\hline Bachelor Degree & $104(67.10 \%)$ & $32(72.73 \%)$ & $136(68.34 \%)$ & 137 & $68.2 \%$ & $>0.05$ \\
\hline Diploma & $3(1.94 \%)$ & $3(6.82 \%)$ & $6(3.02 \%)$ & 6 & $3.0 \%$ & $>0.05$ \\
\hline High school & $26(16.77 \%)$ & $4(9.09 \%)$ & $30(15.08 \%)$ & 30 & $14.9 \%$ & $>0.05$ \\
\hline Intermediate School & $1(0.65 \%)$ & $0(0.00 \%)$ & $1(0.50 \%)$ & 1 & $0.5 \%$ & $>0.05$ \\
\hline Primary School & $1(0.65 \%)$ & $0(0.00 \%)$ & $1(0.50 \%)$ & 1 & $0.5 \%$ & $>0.05$ \\
\hline Not educated & $1(0.65 \%)$ & $0(0.00 \%)$ & $1(0.50 \%)$ & 1 & $0.5 \%$ & $>0.05$ \\
\hline Answered question & $155(77.89 \%)$ & $44(22.11 \%)$ & 199 & 201 & & \\
\hline Skipped question & & & 2 & 0 & & \\
\hline
\end{tabular}

* There is a statistically differences $(p>0.05)$ 


\begin{tabular}{|c|c|c|c|c|c|c|c|c|c|}
\hline Answer Options & 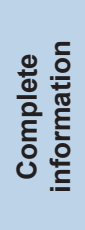 & 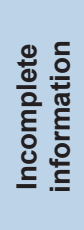 & 竞 & 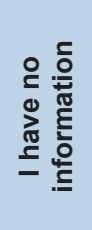 & 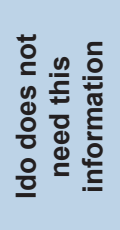 & 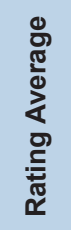 & 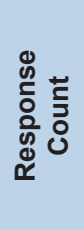 & 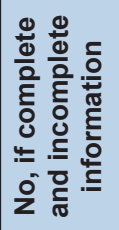 & 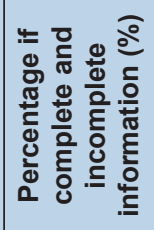 \\
\hline Adverse drug reaction & 44 & 84 & 54 & 16 & 2 & 3.76 & 200 & 128 & 64.00 \\
\hline Medication errors & 32 & 75 & 52 & 42 & 0 & 3.48 & 201 & 107 & 53.23 \\
\hline Drug poisoning & 31 & 58 & 50 & 60 & 1 & 3.29 & 200 & 89 & 44.50 \\
\hline Drug noncompliance & 76 & 74 & 33 & 13 & 2 & 4.06 & 198 & 150 & 75.76 \\
\hline Medication without indications & 80 & 67 & 31 & 16 & 7 & 3.98 & 201 & 147 & 73.13 \\
\hline Drug interactions & 24 & 51 & 45 & 75 & 5 & 3.07 & 200 & 75 & 37.50 \\
\hline An indications without medication & 64 & 60 & 35 & 39 & 2 & 3.73 & 200 & 124 & 62.00 \\
\hline \multicolumn{7}{|l|}{ answered question } & 201 & & \\
\hline \multicolumn{7}{|l|}{ skipped question } & 0 & & \\
\hline
\end{tabular}

\begin{tabular}{|c|c|c|c|c|c|c|c|c|c|c|c|c|c|c|}
\hline $\begin{array}{l}\text { Characteristics } \\
\text { Adverse Drug Reaction }\end{array}$ & \multicolumn{2}{|c|}{$\begin{array}{l}\text { Complete } \\
\text { information }\end{array}$} & \multicolumn{2}{|c|}{$\begin{array}{l}\text { Incomplete } \\
\text { information }\end{array}$} & \multicolumn{2}{|c|}{$\begin{array}{l}\text { Weak } \\
\text { information }\end{array}$} & \multicolumn{2}{|c|}{$\begin{array}{l}\text { I have no } \\
\text { information }\end{array}$} & \multicolumn{2}{|c|}{$\begin{array}{l}\text { Ido does not } \\
\text { need this } \\
\text { information }\end{array}$} & \multicolumn{2}{|l|}{ Total } & $\begin{array}{l}\text { Weighted } \\
\text { Average }\end{array}$ & $\begin{array}{l}P \\
\text { value }\end{array}$ \\
\hline Healthcare Professionals & $44.19 \%^{*}$ & 19 & $41.86 \%$ & 18 & $13.95 \%^{*}$ & 6 & $0.00 \%{ }^{*}$ & 0 & $0.00 \%$ & 0 & $21.61 \%$ & 43 & 4.3 & ${ }^{*}<0.05$ \\
\hline Patients & $15.48 \%{ }^{*}$ & 24 & $41.94 \%$ & 65 & $30.97 \%^{*}$ & 48 & $10.32 \%^{*}$ & 16 & $1.29 \%$ & 2 & $77.89 \%$ & 155 & 3.6 & $*<0.05$ \\
\hline Total & $21.61 \%$ & 43 & $41.71 \%$ & 83 & $27.14 \%$ & 54 & $8.04 \%$ & 16 & $1.01 \%$ & 2 & $100.00 \%$ & 199 & & \\
\hline \multicolumn{15}{|l|}{ Medication errors } \\
\hline Healthcare Professionals & $43.18 \%$ * & 19 & $43.18 \%$ & 19 & $9.09 \% *$ & 4 & $4.55 \%^{*}$ & 2 & $0.00 \%$ & 0 & $22.11 \%$ & 44 & 4.25 & $*<0.05$ \\
\hline Patients & $8.39 \%^{*}$ & 13 & $35.48 \%$ & 55 & $30.32 \%^{*}$ & 47 & $25.81 \%^{*}$ & 40 & $0.00 \%$ & 0 & $77.89 \%$ & 155 & 3.26 & ${ }^{*}<0.05$ \\
\hline Total & $16.08 \%$ & 32 & $37.19 \%$ & 74 & $25.63 \%$ & 51 & $21.11 \%$ & 42 & $0.00 \%$ & 0 & $100.00 \%$ & 199 & & \\
\hline \multicolumn{15}{|l|}{ Drug poisoning } \\
\hline Healthcare Professionals & $34.09 \%^{*}$ & 15 & $45.45 \%^{*}$ & 20 & $15.91 \%$ & 7 & $4.55 \%^{*}$ & 2 & $0.00 \%$ & 0 & $22.11 \%$ & 44 & 4.09 & $*<0.05$ \\
\hline Patients & $10.39 \%^{*}$ & 16 & $24.03 \%^{*}$ & 37 & $27.92 \%$ & 43 & $37.01 \%^{*}$ & 57 & $0.65 \%$ & 1 & $77.39 \%$ & 154 & 3.06 & ${ }^{*}<0.05$ \\
\hline Total & $15.58 \%$ & 31 & $28.64 \%$ & 57 & $25.13 \%$ & 50 & $29.65 \%$ & 59 & $0.50 \%$ & 1 & $100.00 \%$ & 199 & & \\
\hline \multicolumn{15}{|l|}{ Drug noncompliance } \\
\hline Healthcare Professionals & $62.79 \% *$ & 27 & $25.58 \%$ & 11 & $11.63 \%^{*}$ & 5 & $0.00 \%$ & 0 & $0.00 \%$ & 0 & $21.61 \%$ & 43 & 4.51 & ${ }^{*}<0.05$ \\
\hline Patients & $32.03 \%^{*}$ & 49 & $39.87 \%$ & 61 & $18.30 \%^{*}$ & 28 & $8.50 \%$ & 13 & $1.31 \%$ & 2 & $76.88 \%$ & 153 & 3.93 & $*<0.05$ \\
\hline Total & $38.19 \%$ & 76 & $36.18 \%$ & 72 & $16.58 \%$ & 33 & $6.53 \%$ & 13 & $1.01 \%$ & 2 & $100.00 \%$ & 199 & & \\
\hline \multicolumn{15}{|c|}{ Medication without indications } \\
\hline Healthcare Professionals & $63.64 \%^{*}$ & 28 & $29.55 \%$ & 13 & $4.55 \%{ }^{*}$ & 2 & $2.27 \%$ & 1 & $0.00 \%$ & 0 & $22.11 \%$ & 44 & 4.55 & ${ }^{*}<0.05$ \\
\hline Patients & $33.55 \%^{*}$ & 52 & $34.19 \%$ & 53 & $18.71 \%^{*}$ & 29 & $9.68 \%$ & 15 & $3.87 \%$ & 6 & $77.89 \%$ & 155 & 3.84 & ${ }^{*}<0.05$ \\
\hline Total & $40.20 \%$ & 80 & $33.17 \%$ & 66 & $15.58 \%$ & 31 & $8.04 \%$ & 16 & $3.02 \%$ & 6 & $100.00 \%$ & 199 & & \\
\hline \multicolumn{15}{|l|}{ Drug interactions } \\
\hline Healthcare Professionals & $29.55 \% *$ & 13 & $43.18 \%^{*}$ & 19 & $15.91 \%$ & 7 & $9.09 \%^{*}$ & 4 & $2.27 \%$ & 1 & $22.11 \%$ & 44 & 3.89 & $*<0.05$ \\
\hline Patients & $7.14 \%^{*}$ & 11 & $20.13 \%^{*}$ & 31 & $24.68 \%$ & 38 & $45.45 \%^{*}$ & 70 & $2.60 \%$ & 4 & $77.39 \%$ & 154 & 2.84 & $*<0.05$ \\
\hline Total & $12.06 \%$ & 24 & $25.13 \%$ & 50 & $22.61 \%$ & 45 & $37.19 \%$ & 74 & $2.51 \%$ & 5 & $100.00 \%$ & 199 & & \\
\hline \multicolumn{15}{|c|}{ Indications without medication } \\
\hline Healthcare Professionals & $60.47 \%^{*}$ & 26 & $23.26 \%$ & 10 & $11.63 \%$ & 5 & $4.65 \%$ & 2 & $0.00 \%{ }^{*}$ & 0 & $21.61 \%$ & 43 & 4.4 & ${ }^{*}<0.05$ \\
\hline Patients & $24.52 \%^{*}$ & 38 & $31.61 \%$ & 49 & $18.71 \%$ & 29 & $23.87 \%$ & 37 & $1.29 \% *$ & 2 & $77.89 \%$ & 155 & 3.54 & ${ }^{*}<0.05$ \\
\hline Total & $32.16 \%$ & 64 & $29.65 \%$ & 59 & $17.09 \%$ & 34 & $19.60 \%$ & 39 & $1.01 \%$ & 2 & $100.00 \%$ & 199 & & \\
\hline Answered & & & & & & & & & & & & 199 & & \\
\hline Skipped & & & & & & & & & & & & 0 & & \\
\hline
\end{tabular}

* There are a statistical differences in knowledge type drug-related problems with the patients and healthcare professionals ( $p>0.05$ ) 
(75.76\%), and medication without indication $147(73.1 \%)$, while an adequate revealed information of adverse drug reaction 128 (64\%), and an indication without medication $124(62 \%)$. The imperfect information found about drug interaction 75 (37.5\%) and drug poisoning $89(44.5 \%)$.as explored in Table 2. The healthcare provider higher knowledge with complete information on all types of drug-related problems and there is statistically significant in the knowledge of drug-related problems between patients and healthcare professionals $(\mathrm{p}<0.5)$ as explored in Table 3 . The most frequent drugrelated problems occurred with the patient last year at least once; it was drug noncompliance 142 (71.4\%), indications without medication 100 (50\%), and adverse medication events $80(40 \%)$. There is no statistically significant in the occurrence last year of drug-related problems because of patient and healthcare professionals $(p>0.5)$ as explored in Table 4 . The most resources information on drug-related problems used were the internet, medicine leaflet, and healthcare practitioners.It is statistically significant in the type of resources and each drug-related problems between patient and healthcare professionals $(p<0.5)$ expect the drug poisoning problems. For instance, the number of resources of adverse drug reaction the healthcare practitioner and drug information center much higher in the healthcare professionals than the patient. The patient had statistically significantly higher than healthcare professionals did in the type of resources drug pamphlets with medications errors and drug non-compliance problems. There is no statistically significant between patient and healthcare professionals with internet resources of all type of drug-related problems as explored in Table 5 and 6.

\section{DISCUSSION}

The pharmacy administration at Ministry of Health released several pharmacy practice program including patient medications counseling services. ${ }^{[8-9]}$ The program should implement with ambulatory care services, during patient discharge, and established patient counseling clinic operated by a pharmacist. During patient counseling process, the patient discussed all first knowledge of drug information and including drug-related problems. That has to increase patient medications adherence, raise the patient satisfaction of pharmacy services, and prevent misconception of drug usage and avoidance of unnecessary coast on healthcare services. The investigator tried to explore the healthcare professionals and patient attitudes and perspective toward drug-related problems. The finding of the study showed that is the most patients had good knowledge related the non-compliance, the medications without indication. That has explained the feedback knowledge of drug-related problems, and the necessary perception the importance of non-adherence of medications and not taking any drug without particular indication. The responders showed adequate knowledge of adverse drug reaction and indication without medications and related the patient counseling program does not exist at most of Ministry of health hospitals. While the patients showed reduced knowledge of drug interactions and poisoning. That is due to absent from patient education program and public education of medications and drug misadventures at hospitals. The patient maybe gained that good perception of some drug-related problems because it previously occurred with them. For

\begin{tabular}{|c|c|c|c|c|c|c|c|c|}
\hline Answer Options & Once & 2-5 Times & 6-10 Times & $\begin{array}{l}\text { More than } \\
\text { ten times }\end{array}$ & Never & $\begin{array}{l}\text { Response } \\
\text { Count }\end{array}$ & $\begin{array}{l}\text { No of } \\
\text { responders } \\
\text { had DRP at } \\
\text { least once }\end{array}$ & $\begin{array}{l}\text { Percentages }(\%) \\
\text { of responders } \\
\text { had DRP at least } \\
\text { once }\end{array}$ \\
\hline Medication adverse reaction & 48 & 27 & 3 & 2 & 120 & 200 & 80 & 40.00 \\
\hline Medication errors & 28 & 8 & 1 & 1 & 162 & 200 & 38 & 19.00 \\
\hline Drug poisoning & 9 & 4 & 0 & 0 & 188 & 201 & 13 & 6.47 \\
\hline Drug non-compliance & 32 & 69 & 23 & 18 & 57 & 199 & 142 & 71.36 \\
\hline Medication without indications & 24 & 30 & 5 & 14 & 127 & 200 & 73 & 36.50 \\
\hline Drug interactions & 10 & 12 & 5 & 2 & 170 & 199 & 29 & 14.57 \\
\hline Indications without medication & 26 & 57 & 10 & 7 & 100 & 200 & 100 & 50.00 \\
\hline answered question & & & & & & 201 & & \\
\hline skipped question & & & & & & 0 & & \\
\hline
\end{tabular}

There are no statistical differences in drug-related problems occurrences last years between patients and healthcare professional ( $p>0.05$ )

\begin{tabular}{|c|c|c|c|c|c|c|c|c|}
\hline Answer Options & $\begin{array}{l}\text { Health } \\
\text { practitioners }\end{array}$ & $\begin{array}{l}\text { Drug } \\
\text { pamphlet }\end{array}$ & $\begin{array}{l}\text { The } \\
\text { internet }\end{array}$ & $\begin{array}{l}\text { Drug } \\
\text { information } \\
\text { center }\end{array}$ & $\begin{array}{l}\text { Lectures } \\
\text { at } \\
\text { hospitals }\end{array}$ & $\begin{array}{l}\text { Lectures } \\
\text { at markets }\end{array}$ & Others & $\begin{array}{l}\text { Response } \\
\text { Count }\end{array}$ \\
\hline Adverse Drug Reaction & 63 & 158 & 135 & 12 & 12 & 9 & 19 & 201 \\
\hline Medication Errors & 65 & 101 & 123 & 10 & 14 & 5 & 23 & 196 \\
\hline Drug poisoning & 60 & 99 & 120 & 15 & 21 & 7 & 24 & 195 \\
\hline Drug noncompliance & 73 & 101 & 110 & 11 & 12 & 6 & 28 & 197 \\
\hline Medication without indications & 72 & 91 & 115 & 6 & 10 & 6 & 31 & 199 \\
\hline Drug Interaction & 59 & 113 & 112 & 12 & 12 & 2 & 21 & 193 \\
\hline Indications without medication & 83 & 92 & 113 & 4 & 13 & 3 & 27 & 199 \\
\hline Total & 475 & 755 & 828 & 70 & 94 & 38 & 173 & \\
\hline \multicolumn{8}{|l|}{ answered question } & 201 \\
\hline \multicolumn{8}{|l|}{ skipped question } & 0 \\
\hline
\end{tabular}


Alomi, et al.: Attitudes about drug related problems among HCPs and Patients

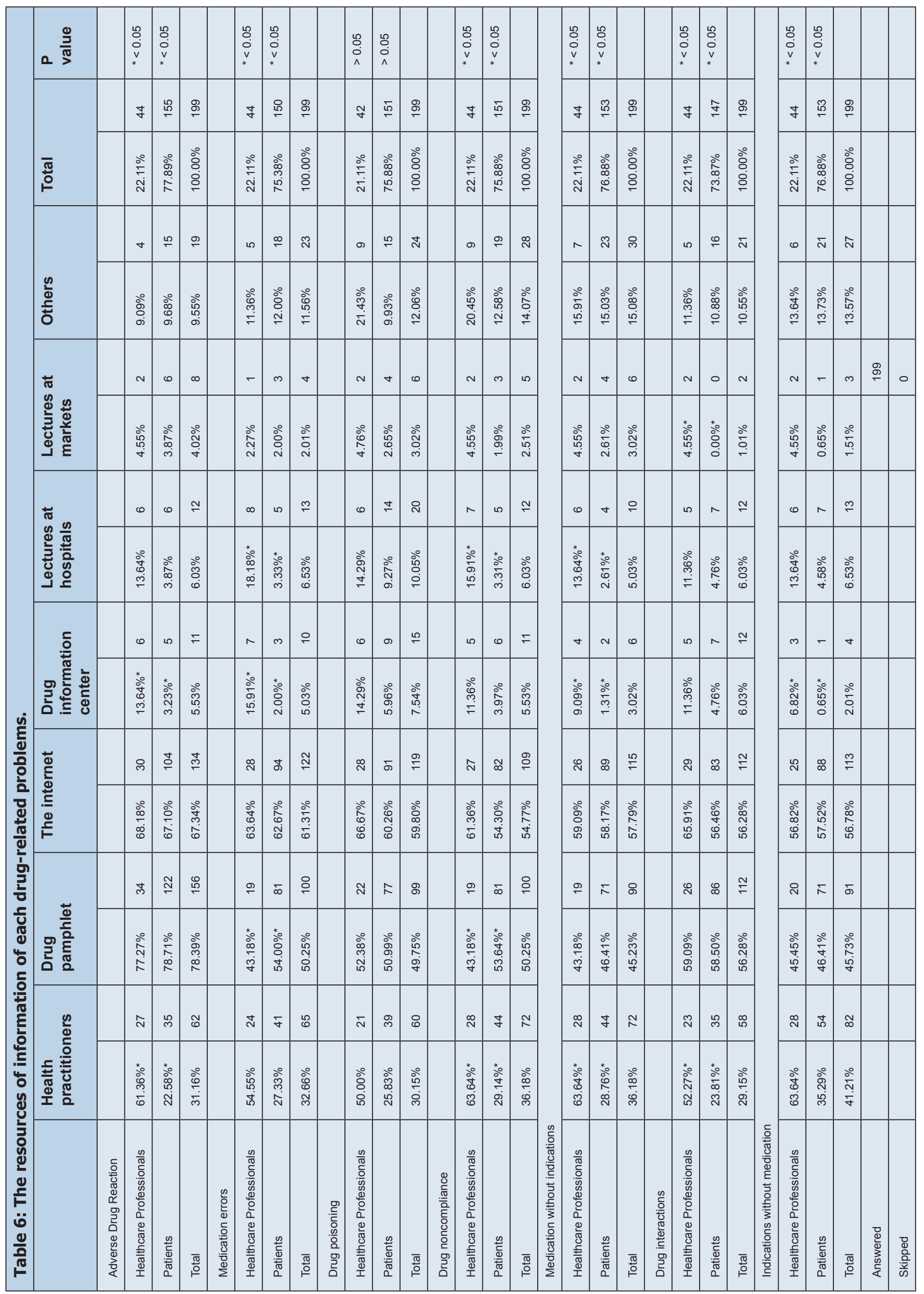




\section{Alomi, et al.: Attitudes about drug related problems among HCPs and Patients}

instance, the non-compliance problem is the highest one with indication without medications and adverse drug reaction. That is good or simple may gain from their experience only. Most of the drug-related problems knowledge of healthcare professional had higher knowledge with statistical differences than the patients. That is a typical finding based on their primary information of their specialties. The most frequent drug-related problems occurred with responders last year at least once; it was drug noncompliance, indications without medication, and adverse medication events, and there are no statistical differences in the occurrences of all drug-related problems between healthcare professionals and patients. That has reflected maybe the lifestyle behavior with both healthcare professional and patients. The occurrences of all drug-related problems resemble what reported by Kjeldsen, LJ et al. ${ }^{[10]}$ The perceptions of occurrences of medication errors of nurses almost the same or little lower than what reported by You, M et al. ${ }^{[11]}$ The perceptions of occurrences of adverse drug reaction and drug non-compliance was higher than what reported by Willeboordse, $\mathrm{F}$ et al. That's related absent of patient medications counseling and program at healthcare organizations and week health knowledge with emphasis on the medicines information, with lower number of clinical pharmacist to reduce or stop those problems. ${ }^{[6]}$ The most drug-related problems knowledge gained from the internet and drug leaflet and last resources were healthcare professionals because there are not patient medications education programs or drug-related problems follow up the system at Ministry of health hospitals. The knowledge and perception of drugrelated problems are not appropriate that may lead to void prevent those problems and the consequences of complications with the high economic burden on healthcare system at hospitals. There is a difference between healthcare professionals and patient regarding the resources references of drug-related problems knowledge expect drug poisoning. Because most of all healthcare professionals or patients had imperfect knowledge of drug poisoning or their references. Also, there are statistical differences in the resources of drug-related problems adverse drug reaction. The healthcare professionals are higher than patient with drug information services and other healthcare colleagues. That is typical finding become the healthcare professionals more contact with those resources. The patient utilization of drug pamphlets higher than healthcare professionals during referral of medications errors and noncompliance problems because of most of the healthcare professionals referred to scientific references. Others drugrelated problems there are no differences in the type of resources in the drug poisoning, indication without medications and medications without indication. All those problems were the same in term of type resources due the imperfect knowledge of medications resources with drug-related problems in both patient and healthcare professionals most of the results could not compare with other studies that are maybe hard to find studies resemble the current investigations, and maybe the first study discussed all those drug-related problems information issues.

\section{CONCLUSION}

The patient and healthcare professionals had a poor perception of drugrelated problems. Targeting to established drug-related detecting and monitoring and patient medications counseling program implementation is highly recommended at Ministry of health hospitals in Saudi Arabia.

\section{ACKNOWLEDGMENT}

None.

\section{CONFLICT OF INTEREST}

None.

\section{ABBREVIATIONS}

KSA: Kingdom of Saudi Arabia; ASHP: American Society of Health-System Pharmacist; MOH: Ministry of Health; USA: United States of America.

\section{REFERENCES}

1. Strand LM, Morley PC, Cipolle RJ, Ramsey R, Lamsam GD. Drug-related problems: their structure and function. Ann Pharmacother. 1990;24(11):1093-7.

2. American Society of Health-System Pharmacist. ASHP Statement on Pharmaceutical Care. Am J Hosp Pharm. 1993;50:1720-3.

3. American Society of Health-System Pharmacists. ASHP guidelines on a standardized method for pharmaceutical care. American Society of HealthSystem Pharmacists. Am J Heal Pharm. 1996;53(14):1713-6.

4. Ramalho de Oliveira D, Brummel AR, Miller DB. Medication therapy management: 10 years of experience in a large integrated health care system. J Manag Care Pharm. 2010;16(3):185-95

5. Van den Bemt PM, Van den Bemt PM, Egberts TC, Egberts TC, De Jong-van den Berg LT, De Jong-van den Berg LT, et al. Drug-related problems in hospitalized patients. Drug Saf. 2000;22(4):321-33.

6. Willeboordse F, Grundeken LH, Van den Eijkel LP, Schellevis FG, Elders PJM, Hugtenburg JG. Information on actual medication use and drug-related problems in older patients: questionnaire or interview? Int J Clin Pharm. 2016;38(2):380-7.

7. Pk A, Adepu R. Drug-related problems: An overview of various classification systems. Asian J Pharm Clin Res. 2014;7(4):7-10.

8. Alomi YA, National Pharmacy Practice Programs at Ministry of Health in Saudi Arabia. 2015;1(2):17-8.

9. Alomi Y. National Pharmacy Administration Programs. BAOJ Pharm Sci. 2015;1(2):1-2.

10. Kjeldsen L, Nielsen T, Olesen C. Investigating the Relative Significance of DrugRelated Problem Categories. Pharmacy. 2017;5(2):31.

11. You MA, Choe MH, Park GO, Kim SH, Son YJ. Perceptions regarding medication administration errors among hospital staff nurses of South Korea. Int J Qual Heal Care. 2015;27(4):276-83. 